\author{
Assistant Professor Mihaela MOCANU, PhD \\ Email: mihaela.mocanu@ cig.ase.ro \\ The Bucharest University of Economic Studies \\ Associate Professor Cristian CIUREA, PhD \\ Email: cristian.ciurea@ie.ase.ro \\ The Bucharest University of Economic Studies
}

\title{
DEVELOPING AN INDEX SCORE FOR THE INTERNAL AUDITOR PROFILE IN ROMANIA BASED ON REAL DATA ANALYSIS
}

Abstract. Internal auditing is an independent, objective assurance and consulting activity designed to add value and improve an organization's operations. Internal auditors protect the management and the audit committee members against potential pitfalls. Moreover, they support organizational performance and provide guidance when a new measure is adopted by the organization. Thus, internal auditors play a critical role in any entity, be it public or private. In fulfilling this role, these practitioners must display certain characteristics such as thorough knowledge of professional standards, analytical thinking, communication skills, and integrity. The paper describes in detail the main set of traits that an internal auditor should have when applying for a job in this field. Based on the job postings published on the best known recruiting portals in Romania, we performed a data analysis in order to extract a set of relevant characteristics and to define an index score for the profile of the internal auditor. The resulting index score can be used by employers as a useful instrument to assess potential or actual members of the internal audit function. Additionally, it can be employed for self-assessment by the candidates for a position as internal auditors department. Lastly, our research provides a picture of what exactly are the current requirements on the job market in Romania with respect to this specific and very important category of professionals - the internal auditors.

Keywords: internal auditor, banks, index score, profile, data analysis.

\section{JEL Classification: C81, J24, M42}

\section{Introduction}

The purpose of an audit is to compare what is to what should be (Lee, 2008). The Institute of Internal Auditors (IIA) defines internal auditing as being "an independent, objective assurance and consulting activity designed to add value and improve an organization's operations. It helps an organization accomplish its objectives by bringing a systematic, disciplined approach to evaluate and improve the effectiveness of risk management, control, and governance processes." This

DOI: 10.24818/18423264/53.2.19.06 
definition widens the scope of internal audit. Nowadays, the profession evolved from its traditional role of compliance checking to a stage where organisations consider it a value adding service to them (Suleimana and Dandago, 2014).

In defining internal audit, the IIA Corporate Governance Model resorts to the analogy of a four-legged stool, where internal audit is one of the "legs" of the stool, together with the board, the external audit and the management. From all these governance pillars, the company has day-to-day and direct contact over the entire year with the board and the internal auditing only (Gras-Gil et al., 2014). The role of internal auditing consists in (1) performing assessments that offer assurance concerning the proper design and effective operation of governance structures and processes and (2) providing advice on the improvement of governance structures and processes. The roles of internal auditing are various: assessor, advisor, advocate and catalyst. Therefore, it is one of the key cornerstones of effective corporate governance. As such, the internal auditor and the manager should be considered as partners within an entity, having the same targets, especially that the management has to undertake the recommendations suggested by the auditors (Iovu, 2018).

The interview-based study of Roussy (2013) points out that internal auditors perform two main roles: (1) a protector role, further subdivided into two roles, protective shield and keeper of secrets, and (2) a helper role, also subdivided into two roles, support of organizational performance and guide. First, internal auditors act as protectors to serve as a shield protecting the top manager, the audit committee members and the managers against potential obstacles or pitfalls such as transactions with "ghost-companies" (Constantin, 2018). Internal auditors also act as keepers of secrets - they keep the secrets of top management against audit committee and the secrets of the organization against the public opinion. Second, internal auditors act as helpers. On one hand, they support organizational performance and, on the other hand, they provide guidance when a new management measure is adopted by the organization.

Moreover, Prawitt, Smith, and Wood (2009) emphasize how frequently internal auditors tend to interact with managers. In such interactions, internal auditors are often those primarily responsible for the daily monitoring of management's actions.However, Pickett (2010) notes that, unlike external auditors, internal auditors lack the incentive to treat management as clients and are more inclined to adopt a "policeman approach" which places little emphasis on positive interpersonal interactions with managers. Deloitte (2010) similarly notes that the "police" approach to internal audit can harm the manager-internal auditor relationship, and contend that a dysfunctional relationship between managers and internal auditors contributes to various accounting problems such as material weaknesses, financial restatement, or regulatory compliance (Fanning and Piercey, 2014).

Protiviti conducted a study in 2013, which focused on how internal auditing handles uncertainty, the manner in which it reacts to the frequent and fast changes 
Developing an Index Score for the Internal Auditor Profile in Romania based on Real Data Analysis

of the processes of the economic entities, and the improvement of the collaboration with the other departments of the entity. One of Protiviti's findings (2013) was that the social networks remain a priority. Understanding the way in which the social networks function and develop is critical for the internal auditors in the future. Moreover, Protiviti (2013) emphasizes that internal auditors must improve their skills in the areas of persuasion, negotiation and handling confrontations and that they should work closer with their co-workers in order to diminish risks on the background of an increasingly complex work environment.

Taking into consideration these proven roles of internal auditors in this context, the importance of their soft skills becomes obvious. Additionally, the technical knowledge and the professional experience of internal auditors are also of great significance. There are studies investigating the relationship between the quality of internal auditing and how their contribution in the audited financial statements is assessed. Zain, Subramaniam and Stewart (2006) study two factors affecting the perceived audit quality: on the one hand, the size of the internal audit department, and on the other, the experience of the internal auditors. The results reveal that the greater the experience of the internal auditors, the greater the perceived contribution to the external audit of the work of internal auditors.

On the other hand, for the internal auditing to be effective, it is important to have the necessary resources to satisfy the qualitative and quantitative demands of the audit that is carried out. Prawittet al. (2009) establish that the quality of the internal auditors' work will be higher in the departments that have better prepared and trained internal auditors. According to Zain et al. (2006) and Prawitt et al. (2009), a higher degree and, therefore, more specific training and more knowledge in the accounting field by internal auditors contribute to a better accounting process oversight and, consequently, to a decrease of misstatements occurrences in the financial statements.

In general, the area of internal audit remains under-researched in Romania, at the moment. There are studies on internal audit written by Romanian authors, but the majority of them are not empirical, but mostly conceptual and normative as research approach. Therefore, they are not able to offer an in-depth view on this complex field of research. Fülöp and Szekely (2017) perform a literature review and an analysis of relevant regulations, focusing on the studies related to the evolution of internal auditing carried out worldwide by prestigious international bodies. Chersan (2016) relies on the information provided by The Institute of Internal Auditors Research Foundation (IIARF) which includes data extracted from The Global Internal Audit Common Body of Knowledge (CBOK) database. The study points out the competencies traditionally required from internal auditors, their views on the skills they master and on the scope of their further skill development. Nicula (2017) focuses on a specific work area of internal auditors namely consulting. They conceptually approach the three types of consulting engagements, and perform a comparison between the assurance and the consulting

DOI: 10.24818/18423264/53.2.19.06 
engagements, while analysing good practices in planning and carrying out consulting engagements.

The topic of internal audit in banks has received even less attention in the Romanian academic literature. The following papers are relevant: Stanciu (2010) on the particularities of bank capital adequacy process audit; Matis and Palfi (2009) on the evolution of non-performing loans and the role held by the internal audit of banks in limiting them; Rusu and Rusovici (2006) on how the internal auditing is performed in banks; Dobroțeanu and Dobroțeanu(2006) regarding the relationship between internal auditing and internal control in banking sector. Our research aims at filling in this gap in the academic literature, both in the broad area of internal audit and in the specific area of internal audit in banks.

We have decided to focus on banks, because a sound banking industry builds the fundament of a highly developed and capital-intensive economy (T,urlea et al., 2010; T,urlea, Mocanu, 2016). In comparison to other sectors, banks have more visibility and have a higher product involvement (Fatma et al., 2014). Moreover, banks may engage in excessive risk taking due to their subsidized deposit insurance, high leverage, government guarantees and lack of transparency (Jensen and Meckling, 1976; Macey and O'Hara, 2003). Additionally, banks play the following two essential roles in today's economy: creating money and shaping the investment scenery (Johanisova and Wolf, 2012). Furthermore, banks play a disciplinary part, by enforcing creditor rights upon companies and assessing firm quality (Qian and Yeung, 2014). The research of Ivashina et al. (2009) claims that bank's informational role improves value creation in mergers and acquisitions. Banks are above all important for smaller firms, as argued by the survey of Aaboen et al. (2006). Caprio et al. (2007) stress the fact that when funds are efficiently mobilized and allocated by banks, there is a decrease in the cost of capital, simultaneously with an acceleration of capital accumulation and productivity growth. All in all, we believe that the demand by economists and policy makers for powerful, insightful accounting research in banking has never been higher than currently (Bushman, 2014).

The paper is structured as follows. First, we present the research methodology, inclusively the sample. Secondly, we describe the characteristics that build the internal auditor's profile. Thirdly, we describe the results of our data analysis. Last but not least, the final section presents the conclusions of the research.

\section{Research methodology}

Our data were manually collected from the archive of two very well-known and highly accessed job portals in Romania: www.bestjobs.ro and www.ejobs.ro. The archives of these portals date back from 2011 (in case of www.bestjobs.ro) and 2005 (in case of www.ejobs.ro). The period for which the data was collected spans over the years 2011-2017. Researchers were only interested in internal audit jobs from within different Romanian banks. Therefore, they selected just job announcements that included in their title the keywords "audit" \& "bank" and

DOI: $10.24818 / 18423264 / 53.2 .19 .06$ 
Developing an Index Score for the Internal Auditor Profile in Romania based on Real Data Analysis

"auditor" \& "bank", whereas the field of information systems audit was excluded. This approach ensured that researchers included in the sample only job postings relevant for the research objective, since the title of each announcement contains both the position and the employer's name.

The sample consists of sixty-seven job postings by seventeen different banks, out of which twelve are commercial banks with their majority of shares owned by foreign shareholders. All 17 banks disclosed their names, although this is not a mandatory feature when publishing a job announcement. The majority of the jobs were located in Bucharest, the capital city of Romania, where the head office of the banks is located. Around 63\% of the jobs were drafted in English, while the rest of $37 \%$ of the announcements were published in the local language - Romanian.

The Institute of Internal Auditors (IIA)is an international professional association established in 1941, with global headquarters in the United States of America. The IIA is the profession's global voice, recognized authority, acknowledged leader, chief advocate, and principal educator. The relevant regulatory sources for delineating a profile of the internal auditor are the IIA's International Standards for the Professional Practice of Internal Auditing; the IIA's Conceptual Framework regarding the competencies of internal auditors; the IESBA Code of Ethics for Professional Accountants, as well as the legislation currently in force in Romania.

Table 1 shows the data collection framework used for the purposes of our research. The following paragraphs thoroughly describe each item in this framework and the way the described item contributes to building a truthful profile of the internal auditor.

Table 1. Data collection framework applied to all job postings

\begin{tabular}{|c|c|c|c|c|c|c|}
\hline Category of & & \multirow{5}{*}{$\begin{array}{l}\text { Individual items } \\
\text { University Degree }\end{array}$} & \multirow{5}{*}{\begin{tabular}{|r} 
Acronym \\
UD
\end{tabular}} & \multicolumn{2}{|c|}{ Coding } & \multirow{2}{*}{$\begin{array}{c}\text { Weight } \\
2\end{array}$} \\
\hline \multirow{13}{*}{$\begin{array}{c}\text { A } \\
\text { Background }\end{array}$} & & & & no mention & 0 & \\
\hline & 1 & & & general & 1 & \\
\hline & & & & economics & 2 & \\
\hline & & & & specialized & 3 & \\
\hline & \multirow{3}{*}{2} & \multirow{3}{*}{ Certifications } & \multirow{3}{*}{$\mathrm{C}$} & no mention & 0 & \\
\hline & & & & local & 1 & \\
\hline & & & & international & 2 & \\
\hline & \multirow{5}{*}{3} & \multirow{5}{*}{$\begin{array}{l}\text { Professional } \\
\text { Experience }\end{array}$} & \multirow{5}{*}{$\mathrm{PE}$} & no mention & 0 & \\
\hline & & & & minimum 1 year & 1 & \\
\hline & & & & minimum 2 years & 2 & \\
\hline & & & & minimum 3 years & 3 & \\
\hline & & & & minimum 5 years & 4 & \\
\hline & 4 & Foreign Language & FLS & no mention & 0 & \\
\hline
\end{tabular}

DOI: 10.24818/18423264/53.2.19.06 


\begin{tabular}{|c|c|c|c|c|c|c|}
\hline & \multirow{2}{*}{\multicolumn{2}{|c|}{ Skills }} & & English & \multirow{2}{*}{$\frac{1}{2}$} & \\
\hline & & & & other language & & \\
\hline \multirow{14}{*}{$\begin{array}{c}\text { B } \\
\text { Technical } \\
\text { skills }\end{array}$} & \multirow{2}{*}{5} & \multirow{2}{*}{$\begin{array}{l}\text { Knowledge of } \\
\text { Banking Legislation }\end{array}$} & \multirow{2}{*}{ KBL } & no mention & 0 & \multirow[t]{14}{*}{4} \\
\hline & & & & required & 1 & \\
\hline & \multirow{2}{*}{6} & \multirow{2}{*}{ Knowledge of IFRS } & \multirow{2}{*}{ KI } & no mention & 0 & \\
\hline & & & & required & 1 & \\
\hline & \multirow{2}{*}{7} & \multirow{2}{*}{ Knowledge of RAS } & \multirow{2}{*}{$\mathrm{KR}$} & no mention & 0 & \\
\hline & & & & required & 1 & \\
\hline & \multirow{2}{*}{8} & \multirow{2}{*}{$\begin{array}{l}\text { Knowledge of } \\
\text { Internal Auditing }\end{array}$} & \multirow{2}{*}{ KIA } & no mention & 0 & \\
\hline & & & & required & 1 & \\
\hline & \multirow{4}{*}{9} & \multirow{4}{*}{$\begin{array}{l}\text { Computer } \\
\text { Proficiency }\end{array}$} & \multirow{4}{*}{$\mathrm{CP}$} & no mention & 0 & \\
\hline & & & & Microsoft Excel & 1 & \\
\hline & & & & Microsoft Access & 2 & \\
\hline & & & & other software & 3 & \\
\hline & \multirow{2}{*}{10} & \multirow{2}{*}{ Analytical Thinking } & \multirow{2}{*}{ AT } & no mention & 0 & \\
\hline & & & & required & 1 & \\
\hline \multirow{8}{*}{$\begin{array}{c}\mathrm{C} \\
\text { Soft skills }\end{array}$} & \multirow{2}{*}{11} & \multirow{2}{*}{$\begin{array}{l}\text { Communication } \\
\text { Skills }\end{array}$} & \multirow{2}{*}{ CS } & no mention & 0 & \multirow[t]{8}{*}{1} \\
\hline & & & & required & 1 & \\
\hline & \multirow{2}{*}{12} & \multirow{2}{*}{ Team Spirit } & \multirow{2}{*}{ TS } & no mention & 0 & \\
\hline & & & & required & 1 & \\
\hline & \multirow{2}{*}{13} & Oroanizational Skills & os & no mention & 0 & \\
\hline & & & & required & 1 & \\
\hline & 14 & Other $\mathbf{S o f t} \mathbf{S} k$ ills & OSS & no mention & 0 & \\
\hline & 14 & Uther Soft Sk1lls & USS & required & 1 & \\
\hline & 15 & Reliability & $\mathrm{R}$ & no mention & 0 & 3 \\
\hline D & 15 & Reliability & $\mathrm{R}$ & required & 1 & \\
\hline Character & 16 & Integrity & $\mathrm{I}$ & no mention & 0 & \\
\hline & & & 1 & required & 1 & \\
\hline
\end{tabular}

\section{Defining the set of auditor's characteristics}

\subsection{Background (items 1 to $\mathbf{4}$ from Table 1)}

In Romania, in order to activate as an internal auditor, one must be registered member of the Chamber of Financial Auditors in Romania (CAFR). In order to obtain this qualification, several conditions must be met: the candidate must have a degree from a university or another equivalent level; the candidate must have at least 3 (three) years of relevant experience in the financial and/or accounting field; he/she must have followed a course of theoretical instruction organized or recognized by the Chamber of Financial Auditors in Romania or by the profession's oversight authority ASPAAS (Authority for the Public Oversight of Statutory Audit Activity); the auditor must have performed a three-year-long 
Developing an Index Score for the Internal Auditor Profile in Romania based on Real Data Analysis

practical training in the financial audit activity; and lastly, he/she should have successfully passed the professional competence exam, held at the end of the practical training. Considering these requirements, we included the following items in the category "Background": 1 University Degree; 2 Certifications; 3 Professional Experience; 4 Foreign Language Skills.

\subsection{Technical skills (items 5 to 10 from Table 1)}

Knowledge of Banking Legislation becomes particularly important in the light of the competence core area no. 5 "Business acumen", according to which the internal auditor has the following responsibilities:

- to maintain knowledge of the organization and its risks;

- to maintain industry specific knowledge appropriate to the audit engagements;

- to assess and take account of macro- and microeconomic factors affecting the organization;

- to maintain a current understanding of the latest regulatory and legal framework within which the organization operates;

- to assess and take account of the technical aspects of financial, managerial and cost accounting concepts, standards, systems and reporting processes appropriate to the organization;

- to take account of cultural aspects of the organization; and

- to take account of the mission, strategic objectives and business nature of the organization.

Moreover, according to details given in the core area no. 4 "Governance, risk and control" from the IIA's Conceptual Framework on competencies, the auditor should maintain a comprehensive insight into the organization's current and emerging risk profile and ensure internal audit activities are aligned with this risk profile and with the organisation's. Considering these provisions, internal auditors employed in the banking sector must demonstrate thorough knowledge of the banking regulatory and legal framework, as well as a deep understanding of the banks' corporate environment.

Knowledge of IFRS and Knowledge of RAS are closely connected, since they both refer to the internal auditor's knowledge of the accounting standards international, and local. As stated in the description of the competence core area no. 5 "Business acumen", internal auditors must not merely maintain knowledge of, but also evaluate financial accounting concepts, standards, systems and reporting processes, therefore thorough knowledge of accounting standards applicable in the audited banking institution is extremely important. Since all Romanian banks are requested to draft financial statements in accordance with the international financial reporting standards, knowledge of the Romanian financial reporting framework is not enough and should be complemented by IFRS knowledge, too.

Knowledge of Internal Auditing - Internal auditors must possess the knowledge, skills, or other competencies needed to perform all the engagement or part of it, as

DOI: 10.24818/18423264/53.2.19.06 
requested by the Attribute Standard 1210 „Proficiency” (1210.C1). Moreover, as defined in the competence core area no. 3 "Application of the International Professional Practices Framework" (IPPF), from the IIA's Conceptual Framework, the internal auditor must maintain current knowledge of the IPPF; must demonstrate appropriate use and interpretation of the IPPF; and must adhere to the requirements of the IPPF when planning and conducting an internal audit engagement. The IPPF is the conceptual framework that organises authoritative guidance promulgated by The IIA and comprises the following mandatory elements: Core Principles for the Professional Practice of Internal Auditing; Definition of Internal Auditing; Code of Ethics; International Standards for the Professional Practice of Internal Auditing. In other words, knowledge of the International Professional Practices Framework is knowledge of internal auditing, which is absolutely necessary for someone working in the field.

Computer Proficiency- According to the Attribute Standard 1210 „Proficiency”, internal auditors must have sufficient knowledge of key information technology risks and controls and available technology-based audit techniques to perform their assigned work (1210.A3). The IIA's Conceptual Framework regarding the competencies of internal auditors also points out towards the need for computer proficiency. As part of the competence core area no. 4 „Governance, risk and control", the internal auditor assesses IT governance. Moreover, in line with the same framework, the internal auditor assesses and takes account of how IT contributes to organizational objectives, risks associated with IT, and relevance to the internal audit engagements (core area no. 5 „Business acumen”). Additionally, during audits, the professional should select and use a variety of tools and techniques (inclusively automated) in order to obtain evidence on business processes. The auditor also applies on a regular basis data collection, data mining, data analysis and statistical techniques (core area no. 8 „Critical Thinking”).Taking into consideration all these responsibilities of the internal auditor, the requirement of computer proficiency becomes evident.

Analytical Thinking is defined as the capacity to think in a thoughtful, discerning way, to scrutinize and break down facts and thoughts into their strengths and weaknesses, to solve problems, to analyse data and to recall and use information (Amer, 2005). This ability is fundamental for the internal auditor, and is also explicitly requested by The IIA's Conceptual Framework, which states that, the internal auditor, among other activities:

- applies problem solving techniques for routine situations ;

- selects and uses appropriate research, business intelligence and problem solving techniques to analyse and solve complex situations;

- applies data collection, data mining, data analysis and statistical techniques.

- uses critical thinking to identify and propose tactics for business process improvement;

- $\quad$ assists management in finding practical solutions to address issues identified through audit;

DOI: $10.24818 / 18423264 / 53.2 .19 .06$ 
Developing an Index Score for the Internal Auditor Profile in Romania based on Real Data Analysis

- ensures that information in decision making is relevant, accurate and sufficient;

\subsection{Soft skills (items 11 to 14 from Table 1)}

Communication Skills in the internal audit activity are thoroughly described in the core area no. 6 "Communication" from the IIA's Conceptual Framework regarding auditor's competences. Among other things, the internal auditor is supposed to:

- foster open communication;

- organize and express ideas clearly and with confidence in order to influence others;

- $\quad$ select appropriate communication forms (verbal, non-verbal, visual, written) and media (face to face, electronic, paper-based);

- listen actively, asking questions as required to check own understanding;

- solicit feedback from audience to gauge the effectiveness of the communication;

- interpret and use body language to reinforce communication;

Team Spirit - The internal audit manager and the chief audit executive should have the ability to properly work in a team. According to the core area no. 2 "Internal audit management", they should act as role models by exemplifying high performance for team members, they should delegate tasks in a constructive and supportive manner and they should also provide constructive and timely feedback to help others achieve their goals. Moreover, internal auditors in general, both in executive as well as managerial positions, should display competencies in the core area no. 7 "Persuasion and collaboration". A good internal auditor puts people at ease and builds open, constructive relationships with all parties. $\mathrm{He} / \mathrm{she}$ collaborates with others and also encourages other team members to work collaboratively. Respect, helpfulness and cooperation are his/her main traits and leads by example in this regard. In summary, an ideal internal auditor participates fully as a team player.

Organizational Skills are absolutely necessary in the internal audit activity, as emphasized in the core area no. 9 "Internal audit delivery". First of all, the auditor must ensure that the scope of work is appropriate for the audit assignment. Secondly, the internal auditor plans and conducts audit engagements so as to identify the most important risks and controls in the audited organization. Thirdly, he/she carries out the audit procedures to meet the specific audit engagement objectives, in strict compliance with the organization's audit methodology. In the auditing process, the professional should manages all resources efficiently to make sure the engagement objectives are fulfilled. Last but not least, the internal auditor follows up with management to ensure that management actions have been effectively implemented or that senior management has accepted the risk of not taking action. All these actions require efficiency and persistence, and great time management - in other words, excellent organizational skills.

Other Soft Skills of the internal auditor consist of negotiation and conflict resolution skills. Moreover, an internal auditor is able to skilfully balance

DOI: $10.24818 / 18423264 / 53.2 .19 .06$ 
diplomacy with assertiveness. He/she makes a positive impact on others, demonstrates credibility and secures respect and cooperation.

\subsection{Character (items 15-16 from Table 1)}

Reliability - The internal auditor should ideally strive for quality and excellence and encourage others to do the same. He/she is supposed to take personal accountability for results delivered. Moreover, a distinguishing mark of the auditing profession is the fact that a professional accountant's responsibility is not exclusively to satisfy the needs of an individual client or employer. Auditors generally act in the public interest and are obliged to comply with the Code of Ethics for Professional Accountants (IESBA, 100.1). As provisioned by the Code of Ethics, auditors should at all times act with professionalism and avoid any action that might bring the profession into disrepute (IESBA, 150.1). Moreover, auditors are expected to act with diligence or due care (IESBA, 130.4). Diligence encompasses the responsibility to act according to the requirement of an assignment, carefully, thoroughly and on a timely basis.

Integrity is one of the fundamental ethical principles to be complied with by the internal auditor, in accordance with the IESBA Code of Ethics for Professional Accountants. Integrity requires the auditor to be honest and straightforward in all professional and business relationships. Truthfulness and fair dealing are also part of this requirement (IESBA, 110.1). Moreover, the internal auditor shall not knowingly be associated with information that was furnished recklessly; information that contains a materially false or misleading statement; and should not omit or hide information required for a proper understanding of the facts (IESBA, 110.2). Integrity is particularly important, because the internal auditor should assess the potential for fraud risk, should identify common types of fraud associated with the audited organization, and should ultimately support a culture of fraud risk awareness at all levels of the auditee.

\section{Metrics for defining the internal auditor profile}

In order to establish the definition of the Overall Index Score for the internal auditor, the following metrics were defined based on the data analysis performed.

Table 2 describes from a mathematical point of view each category of items considered when computing the overall index score that builds the internal auditor's profile.

Table 2. Formulas applied to each category of items

\begin{tabular}{|c|c|c|c|}
\hline & Category of items & Individual Items & Range \\
\hline $\mathrm{BS}$ & Background skills & $\begin{array}{l}\text { BS=UD+C+PE+FLS } \\
\text { where } \\
\text { - } \quad U D \in\{0,1,2,3\} \\
\text { - } \quad C \in\{0,1,2\} \\
\text { - } \quad P E \in\{0,1,2,3,4\}\end{array}$ & $\begin{array}{l}\max (B S)=3+2+4+2=11 \\
\min (B S)=0+0+0+0=0\end{array}$ \\
\hline
\end{tabular}


Developing an Index Score for the Internal Auditor Profile in Romania based on Real Data Analysis

\begin{tabular}{|c|c|c|c|}
\hline & & - $\quad F L S \in\{0,1,2\}$ & \\
\hline TS & Technical skills & $\begin{array}{ll}\text { TS}=\mathrm{KBL}+\mathrm{KI}+\mathrm{KR}+\mathrm{KIA}+\mathrm{CP}+\mathrm{AT} \\
\text { where } \\
\text { - } \quad K B L \in\{0,1\} \\
\text { - } \quad K I \in\{0,1\} \\
\text { - } \quad K R \in\{0,1\} \\
\text { - } \quad K I A \in\{0,1\} \\
\text { - } \quad C P \in\{0,1,2,3\} \\
\text { - } \quad A T \in\{0,1\}\end{array}$ & $\begin{array}{l}\max (\mathrm{TS})=1+1+1+1+3+1=8 \\
\min (\mathrm{TS})=0+0+0+0+0+0=0\end{array}$ \\
\hline SS & Soft skills & $\begin{array}{l}\text { SS=CS+TS+OS+OSS } \\
\text { where } \\
\text { - } \quad C S \in\{0,1\} \\
\text { - } \quad T S \in\{0,1\} \\
\text { - } \quad O S \in\{0,1\} \\
\text { - } \quad \text { OSS } \in\{0,1\}\end{array}$ & $\begin{array}{l}\max (\mathrm{SS})=1+1+1+1=4 \\
\min (\mathrm{SS})=0+0+0+0=0\end{array}$ \\
\hline $\mathrm{C}$ & Character & $\begin{array}{l}\mathrm{C}=\mathrm{R}+\mathrm{I} \\
\text { where } \\
\text { - } \quad R \in\{0,1\} \\
\text { - } \quad I \in\{0,1\}\end{array}$ & $\begin{array}{l}\max (C)=1+1=2 \\
\max (C)=0+0=0\end{array}$ \\
\hline$\Sigma$ & $\begin{array}{l}\text { Overall Index } \\
\text { Score }\end{array}$ & $\mathrm{OIS}=\mathrm{BS}+\mathrm{TS}+\mathrm{SS}+\mathrm{C}$ & $\begin{array}{l}\max (\text { OIS })=11+8+4+2=25 \\
\min (\text { OIS })=0+0+0+0\end{array}$ \\
\hline
\end{tabular}

Based on the above formulas in Table 2, we coded each item (from UD to I) for each job posting (from 1 to 67). We saved these measurements in a worksheet and for each job posting $\left(\mathrm{JP}_{\mathrm{i}}\right.$, with $\mathrm{i}=1$ to 67$)$ we computed a score by summing up the values category-wise (background skills; technical skills; soft skills; character) see Table 3. Further, we have normalized these category-wise sums to fit the interval $[0,100]$ based on the following formula:

where:

$$
x_{N}=(b-a) \cdot \frac{X-X \min }{X \max -X \min }+a,
$$

- $[a, b]$ is the interval,

- $\mathrm{x}_{\mathrm{N}}$ the normalized value of the variable $\in\{\mathrm{BS}, \mathrm{TS}, \mathrm{SS}, \mathrm{C}\}$

- $x$ the value of the variable $\in\{B S, T S, S S, C\}$

Table 3 below shows the total score calculated by summing up the values categorywise (background skills; technical skills; soft skills; character).

Table 3. Item-wise measurements made for job postings

\begin{tabular}{|c|c|c|c|c|c|c|c|c|c|c|}
\hline \multirow{2}{*}{$\mathrm{JP}$} & \multicolumn{5}{|c|}{$\mathrm{BS}$} & \multicolumn{6}{|c|}{$\mathrm{TS}$} \\
\cline { 2 - 12 } & $\mathrm{UD}$ & $\mathrm{C}$ & $\mathrm{PE}$ & $\mathrm{FLS}$ & $\mathrm{KBL}$ & $\mathrm{KI}$ & $\mathrm{KR}$ & $\mathrm{KIA}$ & $\mathrm{CP}$ & $\mathrm{AT}$ \\
\hline $\mathrm{JP}_{1}$ & $\mathrm{UD}_{1}$ & $\mathrm{C}_{1}$ & $\mathrm{PE}_{1}$ & $\mathrm{FLS}_{1}$ & $\mathrm{KBL}_{1}$ & $\mathrm{KI}_{1}$ & $\mathrm{KR}_{1}$ & $\mathrm{KIA}_{1}$ & $\mathrm{CP}_{1}$ & $\mathrm{AT}_{1}$ \\
\hline $\mathrm{JP}_{2}$ & $\mathrm{UD}_{2}$ & $\mathrm{C}_{2}$ & $\mathrm{PE}_{2}$ & $\mathrm{FLS}_{2}$ & $\mathrm{KBL}_{2}$ & $\mathrm{KI}_{2}$ & $\mathrm{KR}_{2}$ & $\mathrm{KIA}_{2}$ & $\mathrm{CP}_{2}$ & $\mathrm{AT}_{2}$ \\
\hline
\end{tabular}

DOI: 10.24818/18423264/53.2.19.06 


\begin{tabular}{|c|c|c|c|c|c|c|c|c|c|c|}
$\ldots$ & $\ldots$ & $\ldots$ & $\ldots$ & $\ldots$ & $\ldots$ & $\ldots$ & $\ldots$ & $\ldots$ & $\ldots$ & $\ldots$ \\
\hline $\mathrm{JP}_{\mathrm{i}}$ & $\mathrm{UD}_{\mathrm{i}}$ & $\mathrm{C}_{\mathrm{i}}$ & $\mathrm{PE}_{\mathrm{i}}$ & $\mathrm{FLS}_{\mathrm{i}}$ & $\mathrm{KBL}_{\mathrm{i}}$ & $\mathrm{KI}_{\mathrm{i}}$ & $\mathrm{KR}_{\mathrm{i}}$ & $\mathrm{KIA}_{\mathrm{i}}$ & $\mathrm{CP}_{\mathrm{i}}$ & $\mathrm{AT}_{\mathrm{i}}$ \\
\hline$\ldots$ & $\ldots$ & $\ldots$ & $\ldots$ & $\ldots$ & $\ldots$ & $\ldots$ & $\ldots$ & $\ldots$ & $\ldots$ & $\ldots$ \\
\hline $\mathrm{JP}_{67}$ & $\mathrm{UD}_{67}$ & $\mathrm{C}_{67}$ & $\mathrm{PE}_{67}$ & $\mathrm{FLS}_{67}$ & $\mathrm{KBL}_{67}$ & $\mathrm{KI}_{67}$ & $\mathrm{KR}_{67}$ & $\mathrm{KIA}_{67}$ & $\mathrm{CP}_{67}$ & $\mathrm{AT}_{67}$ \\
\hline
\end{tabular}

\begin{tabular}{|c|c|c|c|c|c|c|}
\hline \multirow{2}{*}{$\mathrm{JP}$} & \multicolumn{9}{|c|}{$\mathrm{SS}$} & \multicolumn{2}{c|}{$\mathrm{C}$} \\
\cline { 2 - 7 } & $\mathrm{CS}$ & $\mathrm{TS}$ & $\mathrm{OS}$ & $\mathrm{OSS}$ & $\mathrm{R}$ & $\mathrm{I}$ \\
\hline $\mathrm{JP}_{1}$ & $\mathrm{CS}_{1}$ & $\mathrm{TS}_{1}$ & $\mathrm{OS}_{1}$ & $\mathrm{OSS}_{1}$ & $\mathrm{R}_{1}$ & $\mathrm{I}_{1}$ \\
\hline $\mathrm{JP}_{2}$ & $\mathrm{CS}_{2}$ & $\mathrm{TS}_{2}$ & $\mathrm{OS}_{2}$ & $\mathrm{OSS}_{2}$ & $\mathrm{R}_{2}$ & $\mathrm{I}_{2}$ \\
\hline$\ldots$ & $\ldots$ & $\ldots$ & $\ldots$ & $\ldots$ & $\ldots$ & \\
\hline $\mathrm{JP}_{\mathrm{i}}$ & $\mathrm{CS}_{\mathrm{i}}$ & $\mathrm{TS}_{\mathrm{i}}$ & $\mathrm{OS}_{\mathrm{i}}$ & $\mathrm{OSS}_{\mathrm{i}}$ & $\mathrm{R}_{\mathrm{i}}$ & $\mathrm{I}_{\mathrm{i}}$ \\
\hline$\ldots$ & $\ldots$ & $\ldots$ & $\ldots$ & $\ldots$ & $\ldots$ & \\
\hline $\mathrm{JP}_{67}$ & $\mathrm{CS}_{67}$ & $\mathrm{TS}_{67}$ & $\mathrm{OS}_{67}$ & $\mathrm{OSS}_{67}$ & $\mathrm{R}_{67}$ & $\mathrm{I}_{67}$ \\
\hline
\end{tabular}

We have re-arranged the job postings in the ascending order of the values of PE (Professional Experience), ranging from 0 (experience not required) to 4 (experience of minimum 5 years required). Our purpose was to analyse the profile of the internal auditor for different levels of experience, so we have eliminated those job postings where no experience was mentioned whatsoever and we have were left with four main clusters to investigate: (1) professional experience of at least 1 year; (2) professional experience of at least 2 years; (3) professional experience between 3 and 5 years; (4) professional experience of more than 5 years. For each job posting $\left(\mathrm{JP}_{\mathrm{i}}\right.$, with $\mathrm{i}=1$ to 67$)$ we have computed an overall index score based on the weights allocated to each category of items, namely $\mathrm{W}_{\mathrm{bs}}=2$ for Background skills, $\mathrm{W}_{\mathrm{ts}}=4$ for Technical skills, $\mathrm{W}_{\mathrm{ss}}=1$ for Soft skills and $\mathrm{W}_{\mathrm{c}}=3$ for Character (see Table 4).

Table 4.Category-wise measurements made for job postings

\begin{tabular}{|c|c|c|c|c|c|c|c|c|c|}
\hline $\mathrm{JP}$ & $\mathrm{BS}$ & $\mathrm{W}_{\mathrm{bs}}$ & $\mathrm{TS}$ & $\mathrm{W}_{\mathrm{ts}}$ & $\mathrm{SS}$ & $\mathrm{W}_{\mathrm{ss}}$ & $\mathrm{C}$ & $\mathrm{W}_{\mathrm{c}}$ & $\begin{array}{c}\text { Overall } \\
\text { Index } \\
\text { Score }\end{array}$ \\
\hline $\mathrm{JP}_{1}$ & $\mathrm{BS}_{1}$ & 2 & $\mathrm{TS}_{1}$ & 4 & $\mathrm{SS}_{1}$ & 1 & $\mathrm{C}_{1}$ & 3 & $\mathrm{OIS}_{1}$ \\
\hline $\mathrm{JP}_{2}$ & $\mathrm{BS}_{2}$ & 2 & $\mathrm{TS}_{2}$ & 4 & $\mathrm{SS}_{2}$ & 1 & $\mathrm{C}_{2}$ & 3 & $\mathrm{OIS}_{2}$ \\
\hline$\ldots$ & $\ldots$ & $\ldots$ & $\ldots$ & $\ldots$ & $\ldots$ & $\ldots$ & $\ldots$ & $\ldots$ & \\
\hline $\mathrm{JP}_{\mathrm{i}}$ & $\mathrm{BS}_{\mathrm{i}}$ & 2 & $\mathrm{TS}_{\mathrm{i}}$ & 4 & $\mathrm{SS}_{\mathrm{i}}$ & 1 & $\mathrm{C}_{\mathrm{i}}$ & 3 & $\mathrm{OIS}_{\mathrm{i}}$ \\
\hline$\ldots$ & $\ldots$ & $\ldots$ & $\ldots$ & $\ldots$ & $\ldots$ & $\ldots$ & $\ldots$ & $\ldots$ & \\
\hline $\mathrm{JP}_{67}$ & $\mathrm{BS}_{67}$ & 2 & $\mathrm{TS}_{67}$ & 4 & $\mathrm{SS}_{67}$ & 1 & $\mathrm{C}_{67}$ & 3 & $\mathrm{OIS}_{67}$ \\
\hline
\end{tabular}


Developing an Index Score for the Internal Auditor Profile in Romania based on Real Data Analysis

In designing this index score, we used a similar approach as the researchers Mazziotta and Pareto (2013), and Zamfiroiu and Ciurea (2017). The overall index score $O I S$ was computed according to the following formula.

$$
O I S_{i}=\frac{B S_{i} \cdot W_{B S}+T S_{i} \cdot W_{T S}+S S_{i} \cdot W_{S S}+C_{i} \cdot W_{C}}{W_{B S}+W_{T S}+W_{S S}+W_{C}}
$$

where:

- $\mathrm{BS}_{\mathrm{i}}-$ Background skills score for the $\mathrm{i}$-th job description

- $\mathrm{W}_{\mathrm{BS}}$-weight for the Background skills score

- $\mathrm{TS}_{\mathrm{i}}-$ Technical skills score for the $\mathrm{i}$-th job description

- $\mathrm{W}_{\mathrm{TS}}$-weight for the Technical skills score

- $\mathrm{SS}_{\mathrm{i}}-$ Soft skills score for the i-th job description

- $\mathrm{W}_{\mathrm{SS}}$-weight for the Soft skills score

- $\mathrm{C}_{\mathrm{i}}-$ Character score for the $\mathrm{i}$-th job description

- $\mathrm{W}_{\mathrm{c}}$-weight for the Character score

The Overall Index Score is one of the most representative indicators that can be used in assessing the skills and knowledge necessary for a very good internal auditor positions.

\section{Results}

The actual results following the analysis of the 67 job postings are displayed in Table 5. All scores have been normalized to fit the interval $[0,100]$ in order to facilitate the user's understanding of a certain value that may have resulted from applying our overall index score model.

Table 5.Category-wise scores and overall index scores for clusters of professional experience

\begin{tabular}{|c|c|c|c|c|c|c|c|c|c|}
\hline \multirow{2}{*}{$\begin{array}{c}\text { Professional } \\
\text { Experience }\end{array}$} & \multicolumn{4}{|c|}{ Background (BS) } & \multicolumn{3}{c|}{ Technical skills (TS) } & \multicolumn{3}{c|}{ Soft skills (SS) } \\
\cline { 2 - 10 } & MIN & MAX & AVG & MIN & MAX & AVG & MIN & MAX & AVG \\
\hline$>=1$ year & 40 & 60 & 50 & - & 17 & 11 & - & 67 & 44 \\
\hline$>=2$ years & 30 & 80 & 56 & - & 100 & 44 & - & 100 & 63 \\
\hline$>=3$ years & 50 & 90 & 76 & - & 83 & 39 & - & 100 & 48 \\
\hline$>=5$ years & 70 & 100 & 83 & 17 & 67 & 50 & 33 & 100 & 67 \\
\hline
\end{tabular}

\begin{tabular}{|c|c|c|c|c|c|c|}
\hline \multirow{2}{*}{$\begin{array}{c}\text { Professional } \\
\text { Experience }\end{array}$} & \multicolumn{3}{|c|}{ Character ('C) } & \multicolumn{3}{c|}{ Overall Index Score } \\
\cline { 2 - 7 } & MIN & MAX & AVG & MIN & MAX & AVG \\
\hline$>=1$ year & - & 50 & 17 & & 42 & 33 \\
\hline
\end{tabular}

DOI: 10.24818/18423264/53.2.19.06 


\begin{tabular}{|c|c|c|c|c|c|c|} 
& & & & 18 & & \\
\hline$>=2$ years & - & 100 & 24 & 40 & 100 & 55 \\
\hline$>=3$ years & - & 100 & 17 & 31 & 84 & 60 \\
\hline$>=5$ years & - & 100 & 50 & 51 & 84 & 74 \\
\hline
\end{tabular}

As expected, the overall index score increases with experience. A junior internal auditor which is required to have at least on 1 year, but not more than 2 years of professional experience has, on average, an overall index score of 33, which is much higher (i.e. 74) in case of senior auditors with more than 5 years of experience. The same ascending trend of the average score is to be noticed in case of the category "Background" (values rise from 50 to 56 to 76 and to 83 for the most experienced practitioners). However, in the case of the other three categories (TS, SS, and C), we notice that the requirements for the auditors with more than 3 years of experience are surprisingly lower than for the professionals with a minimum of 2 years of professional practice. On the other hand, for all these categories, the highest average is to be found for the senior auditors who fall in the range " $>=5$ years": $\mathrm{OIS}_{\mathrm{BS}}=83 ; \mathrm{OIS}_{\mathrm{TS}}=50 ; \mathrm{OIS}_{\mathrm{TS}}=67 ; \mathrm{OIS}_{\mathrm{C}}=51$.

Table 6 displays our results at a more granular level. It contains the average score for each item (corresponding to a trait of the auditor), separated according to the professional experience, namely in four groups: $>=1$ year; $>=2$ years; $>=3$ years and $>=5$ years.

Table 6. Item-wise average scores for each cluster of professional experience

\begin{tabular}{|c|c|c|c|c|c|c|c|c|c|c|c|}
\hline $\begin{array}{l}\text { Professional } \\
\text { experience }\end{array}$ & $\begin{array}{l}\text { University } \\
\text { Degree }\end{array}$ & $\begin{array}{l}\text { Certifi- } \\
\text { cations }\end{array}$ & \multicolumn{2}{|c|}{$\begin{array}{l}\text { Foreign } \\
\text { Language } \\
\text { Skills }\end{array}$} & \multicolumn{2}{|c|}{$\begin{array}{c}\text { Knowledge of } \\
\text { Banking } \\
\text { Legislation }\end{array}$} & \multicolumn{2}{|c|}{$\begin{array}{l}\text { Knowledge } \\
\text { of IFRS }\end{array}$} & \multicolumn{2}{|c|}{$\begin{array}{c}\text { Knowledge } \\
\text { of RAS }\end{array}$} & $\begin{array}{c}\text { Knowledge } \\
\text { of Internal } \\
\text { Auditing }\end{array}$ \\
\hline \multirow[t]{2}{*}{ Value range } & $\mathrm{UD} \in\{0,1,2,3\}$ & $C \in\{0,1,2\}$ & \multicolumn{2}{|c|}{ FLS $\in\{0,1,2\}$} & \multicolumn{2}{|c|}{ KBL $\in\{0,1\}$} & \multicolumn{2}{|c|}{$\mathrm{KI} \in\{0,1\}$} & \multicolumn{2}{|c|}{$\mathrm{KR} \in\{\mathbf{0 , 1}\}$} & KIAE $\in \mathbf{0 , 1}\}$ \\
\hline & A1 & A2 & \multicolumn{2}{|c|}{ A4 } & \multicolumn{2}{|c|}{ B5 } & \multicolumn{2}{|c|}{ B6 } & \multicolumn{2}{|c|}{ B7 } & B8 \\
\hline$>=1$ year & 2.00 & 0.67 & \multicolumn{2}{|l|}{1.33} & & \multicolumn{2}{|r|}{-} & & - \\
\hline$>=2$ years & 2.19 & 0.43 & \multicolumn{2}{|l|}{0.95} & \multicolumn{2}{|c|}{0.48} & \multicolumn{2}{|c|}{0.10} & \multicolumn{2}{|c|}{0.10} & 0.48 \\
\hline$>=3$ years & 2.00 & 1.56 & \multicolumn{2}{|l|}{1.00} & \multicolumn{2}{|c|}{0.56} & \multicolumn{2}{|c|}{0.11} & \multicolumn{2}{|c|}{0.22} & 0.67 \\
\hline$>=5$ years & 1.25 & 2.00 & \multicolumn{2}{|l|}{1.00} & \multicolumn{2}{|c|}{0.25} & \multicolumn{2}{|c|}{-} & & 0.75 \\
\hline $\begin{array}{l}\text { Professional } \\
\text { experience }\end{array}$ & $\begin{array}{l}\text { Computer } \\
\text { Proficiency }\end{array}$ & $\begin{array}{c}\text { Analytica } \\
\text { l } \\
\text { Thinking }\end{array}$ & $\begin{array}{l}\text { Communi } \\
\text { - cation } \\
\text { Skills } \\
\end{array}$ & \multicolumn{2}{|c|}{$\begin{array}{l}\text { Team } \\
\text { Spirit }\end{array}$} & \multicolumn{2}{|c|}{$\begin{array}{c}\text { Organiza- } \\
\text { tional Skills }\end{array}$} & \multicolumn{2}{|c|}{$\begin{array}{l}\text { Other Soft } \\
\text { Skills }\end{array}$} & $\begin{array}{l}\text { Relia- } \\
\text { bility }\end{array}$ & $\begin{array}{l}\text { Inte- } \\
\text { grity }\end{array}$ \\
\hline \multirow[t]{2}{*}{ Value range } & $\mathrm{CP} \in\{0,1,2,3\}$ & AT $\in\{0,1\}$ & $\mathrm{CS} \in\{\mathbf{0 , 1}\}$ & \multicolumn{2}{|c|}{$T S \in\{0,1\}$} & OS $\in\{$ & & OSS $\in$ & $0,1\}$ & $\mathrm{R} \in\{\mathbf{0 , 1}$ & $I \in\{\mathbf{0 , 1}\}$ \\
\hline & B9 & B10 & B11 & & 12 & B13 & & B1 & & B15 & B16 \\
\hline$>=1$ year & 0.67 & - & 0.67 & & 67 & - & & - & & 0.33 & - \\
\hline
\end{tabular}


Developing an Index Score for the Internal Auditor Profile in Romania based on Real Data Analysis

\begin{tabular}{|l|l|l|l|l|l|l|l|l|}
\hline$>=2$ years & 0.86 & 0.62 & 0.81 & 0.38 & 0.43 & 0.29 & 0.29 & 0.19 \\
\hline$>=3$ years & 0.44 & 0.33 & 0.33 & 0.44 & 0.56 & 0.11 & 0.22 & 0.11 \\
\hline$>=5$ years & 1.25 & 0.75 & 0.75 & 0.25 & 0.75 & 0.25 & 0.50 & 0.50 \\
\hline
\end{tabular}

Therefore, by reading and interpreting the data in Table 6 , the following conclusions can be drawn:

- for experienced auditors, the university degree is less important for the employers (average 1.25 for the category " $>=5$ years" compared to an average 2.00 for junior auditors with at least 1 year of experience),

- once experience increases, professional certifications are given increased consideration by the employers ( 0.67 for junior auditors compared to 2.00 for senior auditors);

- knowledge in the specific field of internal auditing is not required for inexperienced auditors (average of 0.00), while for auditors on a higher position, it is considered of high significance (average of 0.75 );

- computer proficiency is expected at all levels of experience, but mostly for the positions that require experience of more than 5 years;

- team spirit is highly desired for lower-level positions, as these require more interactions with colleagues and more dependence on other people's input;

- communication skills are essential, no matter the experience level;

- analytical thinking and organizational skills are most valued in case of senior job offerings, where decision-making is a critical part in the job description;

- regarding the character of a potential candidate in the field of internal auditing, his or her reliability is a trait mentioned by employers, irrespective of the experience needed for the job.

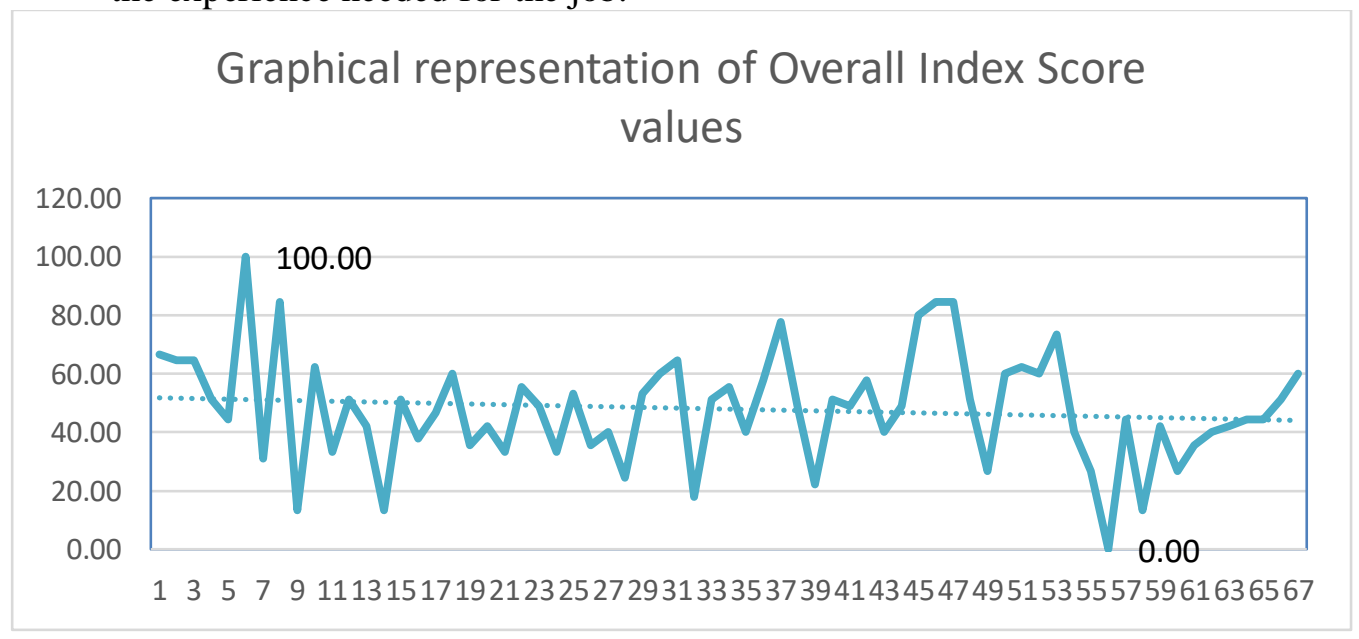

Figure 1. Graphical representation of Overall Index Score

DOI: $10.24818 / 18423264 / 53.2 .19 .06$ 
Figure 1 shows the Graphical representation of Overall Index Score values for the set of 67 job descriptions considered for analysis.

As seen from Figure 1, the values obtained for the Overall Index Score are normalized between 0 and 100 and the results shows that the indicator defined can be used as a strong evaluation score for the internal auditor job.

\section{Conclusions}

Internal auditors play a significant role in influencing managers' judgments. Internal auditing is defined by IIA as an independent, objective assurance, and consulting activity planned and performed for the purpose to add value and improve an organization's operations. Auditing helps companies accomplish their objectives by offering a disciplined and systematic approach to assess and improve the effectiveness of risk management, control, and governance processes. Internal auditors protect the managers and the audit committee members against potential pitfalls or obstacles. Moreover, they support corporate performance and provide guidance when a new measure is adopted by the organization. This enlarged role increases the importance of internal auditing as part of corporate governance, and at the same time it also increases the demands being put on internal auditors. Their role requires a high level of skills and knowledge.

The objective of our paper was to thoroughly describe the main set of traits that a person should have when successfully applying for a job as internal auditor in the Romanian banking sector. Our research is empirical. We have gathered actual data from 67 job postings published on the best known recruiting portals in Romania over the period 2011-2017. Based on coding the requirements in the sampled job offers, we designed an index score that builds the profile of an internal auditor. The score comprises four categories of characteristics: (A) Background; (B) Technical Skills; (C) Soft skills; and (D) Character. Firstly, the following items contribute to the background of an internal auditor: university degree, certifications, professional experience and foreign language skills. Secondly, the technical skills refer to knowing the specific banking legislation and having a grasp of both IFRS (International Financial Reporting Standards) and RAS (Romanian Accounting Standards). Computer proficiency, analytical thinking, as well as knowledge in the particular area of internal auditing are also required in the category of "technical skills". It was found that employers appreciate not only technical skills, but also the soft skills of an internal auditor. Communication skills, team spirit, organizational skills and other soft skills such as negotiation skills are mentioned in the analysed job offers. Lastly, the internal auditor must observe the ethical requirements, as requested by the profession. Thus, an important part of the profile is their character - their reliability and integrity, since the lack thereof makes all other traits lose their value.

The resulting index score can be used by employers as a useful instrument to assess potential or actual members of the internal audit function. Additionally, it can be employed for self-assessment by the candidates for a position as internal auditors 
Developing an Index Score for the Internal Auditor Profile in Romania based on Real Data Analysis

department. All things considered, our research provides a picture of what exactly are the current requirements on the job market in Romania with respect to this specific and very important category of professionals - the internal auditors.

\section{REFERENCES}

[1] Aaboen L., Lindelo P., von Koch C., Löfsten H. (2006), Corporate Governance and Performance of Small High-Tech Firms in Sweden, Technovation 26, 955968;

[2] Amer A. (2005), Analytical Thinking; Center for Advancement of Postgraduate Studies and Research in Engineering Sciences, Faculty of Engineering - Cairo University (CAPSCU), Cairo;

[3] Bushman R. (2014), Thoughts on Financial Accounting and the Banking Industry; Journal of Accounting and Economics 58 (2014) 384-395;

[4] Caprio G., Laevenb L., Levined R. (2007), Governance and Bank Valuation; Journal of Financial Intermediation 16, 584-617;

[5] Chersan, I.C. (2016), Internal Audit Practices and Trends in Romania and Worldwide; Audit Financiar, vol. XIV, no. 9(141), 987-1002, DOI: 10.20869/AUDITF/2016/141/987;

[6] Constantin S.-B. (2018), Ghost Companies, Fiction or Reality?; Ovidius University Annals, Economic Sciences Series, Volume XVIII, Issue 2 /2018;

[7] Dascălu, E.D. (2016), Model for Dimensioning the Audit Structures in the Public Sector; Audit Financiar, vol. XIV, no. 8(140),909-917;

[8] Deloitte (2010), The Broken Triangle? Improving the Relationship between Internal Audit, Management, and the Audit Committee. New York: Deloitte Development LLC;

[9] Fanning K., Piercey M.D. (2014), Internal Auditors' Use of Interpersonal Likability, Arguments, and Accounting Information in a Corporate Governance Setting; Accounting, Organizations and Society 39, 575-589;

[10] Fatma M., Rahman Z., Khan I. (2014), Multi-Item Stakeholder Based Scale to Measure CSR in the Banking Industry; International Strategic Management Review 2, 9-20;

[11]Fülöp, M.T.,Szekely, S.V. (2017), The Evolution of the Internal Auditing Function in the Context of Corporate Transparency; Audit Financiar, vol. XV, no. 3(147), 440-450;

[12]Gras-Gil E., Marín-Hernándezby S., García-Pérez de Lema D. (2014), Quality of Internal Audit and Financial Reporting in the Spanish Banking Industry; Revista de Contabilidad - Spanish Accounting Review;

[13]Iovu, C. (2018), The Role and Key Objectives of the Company's Internal Audit Process; Journal of Accounting, Finance and Auditing Studies 4/3, pp. 19-44

[14]Ivashina V., Nair V., Saunders, A., Massound, N., Stover, R., (2009), Bank Debt and Corporate Governance; Review of Financial Studies 22 (1), 41-77;

[15]Jensen M., Meckling W. (1976), Theory of the Firm: Managerial

DOI: 10.24818/18423264/53.2.19.06 
Behavior, Agency Costs, and Ownership Structure; Journal of Financial Economics 3, 305-360;

[16] Johanisova N., Wolf S. (2012), Economic Democracy: A Path for the Future? ; Futures 44, 562-570;

[17] Lee G. H. (2008), Rule-based and Case-based Reasoning Approach for Internal Audit of Bank; Knowledge-Based Systems 21, 140-147;

[18] Macey J., O'Hara M. (2003), The Corporate Governance of Banks; FRBNY Economic Policy Review, April, 91-107;

[19] Matiș D., Palfi C. (2009), Non-performing Loans' Evolution in Romania and Banking Internal Audit's Role in their Limitation; Audit Financiar, 8, 34-41;

[20] Mazziotta M., Pareto A. (2013), Methods for Constructing Composite Indices: One for All or All for One? ; Rivista Italiana di Economia Demografia e Statistica Volume LXVII n. 2 Aprile-Giugno 2013, 67-80;

[21] Nicula, V.C. (2017), Consulting Provided by the Internal Public Audit Function; Audit Financiar, vol. XV, no. 4(148)/2017, 677-685;

[22] Pickett, K. H. S. (2010), The Internal Auditing Handbook (3rd ed.). West

Sussex, England: John Wiley \& Sons Ltd.;

[23] Prawitt, D. F., Smith, J. L., Wood, D. A. (2009), Internal Audit Quality and Earnings Management. The Accounting Review, 84(4), 1255-1280;

[24] Protiviti (2014), Assessing the Top Priorities for Internal Audit Functions. 2014 Internal Audit Capabilities and Needs Survey, available online at: https://www.protiviti.com/en-US/Documents/Surveys/2014-InternalAudit-Capabilities-and-Needs-Survey-Protiviti.pdf, accessed on 26.03.2017;

[25] Qian M., Yeung B. (2014), Bank Financing and Corporate Governance; Journal of Corporate Finance;

[26] Roussy M. (2013), Internal Auditors' roles: From Watchdogs to Helpers and Protectors of the Top Manager; Critical Perspectives on Accounting 24, 550-571;

[27] Rusu G., Rusovici A. (2006), How is the Internal Audit Done in Banks?; Audit Financiar 4 (2006), 33-36;

[28] Stanciu V. (2016), Trends and Priorities in Internal Audit; Audit Financiar, 14, 1003-1008;

[29] Suleimana D. M., Dandago K. I. (2014), The Extent of Internal Audit Functions Outsourcing by Nigerian Deposit Money Banks; Procedia-

Social and Behavioral Sciences 164, 222 -229;

[30] Țurlea E, Mocanu M., Radu C., (2010), Corporate Governance in the Banking Industry; Journal of Accounting and Management Information Systems, 3(9), 379-402;

[31] Tुurlea, E., Mocanu, M. (2016), The Profile of the Internal Auditor in the Romanian Banking Sector; Audit Financiar, vol. XIV, no. 11(143), 1235-1245;

[32] Zain, M. M., Subramaniam, N. y Stewart, J. (2006), Internal Auditors' Assessment of their Contribution to Financial Statement Audits: The Relation with Audit Committee and Internal Audit Function Characteristics; International Journal of Auditing, 10, 1-18; 
Developing an Index Score for the Internal Auditor Profile in Romania based on Real Data Analysis

[33] Zamfiroiu A., Ciurea C. (2017), A Model for Users' Profile Recognition Based on their Behavior in Online Applications; Economic Computation and Economic Cybernetics Studies and Research, 2(51), 181 - 194. 